\title{
Micronutrient evaluation of sweet orange orchards in district Swabi, Khyber Pakhtunkhwa, Pakistan
}

\author{
Muhammad Safdar Jadoon ${ }^{1}$, Mehrunisa Memon ${ }^{1 *}$, Noor-un-Nisa \\ Memon $^{2}$, Muhammad Nawaz Kandhro ${ }^{3}$, Hidayatullah ${ }^{4}$ and Tanveer \\ Ali Sial ${ }^{5}$ \\ 1. Department of Soil Science, Sindh Agriculture University, Tandojam-Pakistan \\ 2. Department of Horticulture, Sindh Agriculture University, Tandojam-Pakistan \\ 3. Department of Agronomy, Sindh Agriculture University, Tandojam-Pakistan \\ 4. Directorate of Agriculture Research Soil and Water Testing, Sariab Quetta-Pakistan \\ 5. College of Resources \& Environment, Northwest A \& F University, Yangling, Shaanxi, 712100-China \\ *Corresponding author's email: nisamemon@gmail.com
}

Citation

Muhammad.Safdar Jadoon, Mehrunisa Memon, Noor-un-Nisa Memon, Muhammad.Nawaz Kandhro, Hidayatullah and Tanveer Ali Sial. Micronutrient evaluation of sweet orange orchards in district Swabi, Khyber Pakhtunkhwa, Pakistan. Pure and Applied Biology. Vol. 9, Issue 1, pp66-73.

http://dx.doi.org/10.19045/bspab.2020.90008

\begin{tabular}{llll}
\hline \hline Received: 01/06/2019 & Revised: 24/08/2019 & Accepted: 05/09/2019 & Online First: 20/09/2019 \\
\hline
\end{tabular}

\section{Abstract}

District Swabi of Khyber Pakhtunkhwa province is well known for growing sweet oranges. Without inorganic fertilizer, the yield and quality of oranges have been declining over time. Keeping in mind the importance of micronutrients in citrus, survey of 20 sweet orange orchards in the area was planned. Composite soil $(0-30 \mathrm{~cm})$ and relevant leaf tissue $\left(4^{\text {th }}\right.$ leaf from top) samples of non-fruiting branches (10-15 years) were collected during July-August, 2015. Majority of the soils were light, having sandy loam $(60 \%)$ as a dominant texture with remaining as silt loam and loam. All the soils were non-saline $\left(<2 \mathrm{dS} \mathrm{m}^{-1}\right)$ and medium alkaline (7.5-8.3) in reaction with overall adequate $(>1.29 \%)$ organic matter content. Majority of the samples were adequate in available B (95\%), $\mathrm{Cu}(95 \%), \mathrm{Fe}$ (65\%), $\mathrm{Mn}(60 \%)$ and $\mathrm{Zn}(55 \%)$. In contrast to soil, leaf tissue analysis illustrated that all $100 \%$ samples (B, $\mathrm{Cu}, \mathrm{Mn}$ and $\mathrm{Zn})$ and $70 \%(\mathrm{Fe})$ were below the critical limit of each nutrient for citrus. The association between organic matter content and each B (0.53), Fe (0.67) and $\mathrm{Zn}(0.80)$ was linear and significant showing contribution of this pool in available nutrients. The regression coefficient $\left(\mathrm{R}^{2}\right)$ explained a poor and non-significant relationship with only $26 \%(\mathrm{~B}), 3 \%(\mathrm{Cu}), 21 \%(\mathrm{Fe})$, and $18 \%$ $(\mathrm{Mn})$ contribution to leaf tissue nutrients from soil available pool. From this study it is inferred that orchards of district Swabi require application of $\mathrm{B}, \mathrm{Cu}, \mathrm{Fe}, \mathrm{Mn}$, and $\mathrm{Zn}$, with emphasis to regular monitoring and soil testing for specific fertilizer recommendations.

Keywords: B; citrus; $\mathrm{Cu}$; Fe; Leaf tissue; $\mathrm{Mn} ; \mathrm{Zn}$

\section{Introduction}

Pakistan occupies a striking position in citrus production among 15 top citrus producing countries (Brazil, China, USA, India, Mexico and Spain) of the world [1]. In Pakistan cultivation of citrus (lime, lemon, grapefruit, sweet orange and mandarin orange) is carried out on an area of 194,000 hectares with an annual yield of 2.2 million tons [2]. Khyber Pakhtunkhwa (KPK) province is famous for growing sweet oranges "Malta" (Citrus-sinenesis L.) [3]. Buner, Dir, Haripur, Nowshera, Malakand, Swabi and Swat districts together produce 37.7 thousand tons of sweet oranges annually from 4.5 thousand hectares of land [4]. The climatic conditions and soils of this 
area are favorable for the production of sweet oranges [5]. Unfortunately, the citrus orchards of the province have been declining in general and of district Swabi in particular [6]. There may be bundle of reasons for its poor production, however, inadequate and improper fertilization practices may be the main and basic factors to be monitored for poor production of sweet oranges [5]. In addition to macronutrients such as nitrogen $(\mathrm{N})$, phosphorus (P), Potassium (K), Calcium $(\mathrm{Ca})$, Magnesium $(\mathrm{Mg})$ and sulfur (S) while micronutrients are required in minute quantities and play significant role in production and quality of citrus [7]. Boron (B) is required in newly emerging shoot and root, flowering, pollination, seed development and sugar transport synthesis by different plant components [8]. Copper $(\mathrm{Cu})$ is important in providing energy for chemical reactions, iron $(\mathrm{Fe})$ is component of chlorophyll, manganese $(\mathrm{Mn})$ controls the enzyme system and zinc ( $\mathrm{Zn}$ ) plays role in production of enzymes and proteins. Micronutrient decline in sweet orange orchards have been reported by [5, , 10] for Malakand, Swat and Haripur districts of KPK. However, no studies reporting the sweet orange status in Swabi district of the same province, besides, the studies including leaf tissue analysis are scarce.

\section{Materials and methods}

Representative soil and leaf tissue samples were obtained from citrus growing villages i.e. Jhanda, Manai, Topi and Gadoon Industrial Estate of district Swabi, KPK between July and August, 2015. Five orchards of sweet orange variety between 10 and 15 years age were chosen from each village and were further distributed into three sections. Under each section, six trees were selected at random and composited section-wise. Thirty leaves $\left(4^{\text {th }}\right.$ leaf from top), randomly sampled from four to six month old non-fruiting branches were composited to one as detailed by Jones et al. [11]. Same trees were used for the collection of soil samples at surface $(0-30 \quad \mathrm{~cm})$. Representative soil samples were obtained by digging four cores beneath the citrus canopy and composited for each tree. Citrus leaves were decontaminated [12], air-dried in shade, followed by oven drying $\left(65^{\circ} \mathrm{C}\right)$ and finally ground to 20 mesh as given by Ryan et al. [13]. Soils were also dried at room temperature in shade, unnecessary material i.e. stones, roots, etc. ones were removed, crushed and finally brought to $2 \mathrm{~mm}$ particle size using stainless steel sieve.

Leaf citrus and relevant soil samples were subjected to $\mathrm{B}, \mathrm{Cu}, \mathrm{Fe}, \mathrm{Mn}$ and $\mathrm{Zn}$ testing in addition to soil texture, $\mathrm{pH}$ and electrical conductivity (EC) (1:2 soil-water extracts) and organic matter as detailed under Ryan et al. [13]. For B in leaf (leaf tissue B), samples were dry-ashed as given by Jones and Case [14], for remaining micronutrients wet acid digestion method as described by Ryan et al. [13] was used. Boron in soil (available B) was extracted using dilute hydrochloric acid. The quantification of B in leaf and soil samples followed Azomethine-H Method of B determination [15] at $420 \mathrm{~nm}$ using spectrophotometer. Available $\mathrm{Cu}, \mathrm{Fe}, \mathrm{Mn}$ and $\mathrm{Zn}$ were extracted by ammonium bicarbonate-diethylenetriaminepentaacetic acid $\left(\mathrm{NH}_{4} \mathrm{HCO}_{3}\right.$-DTPA) as originally given by Soltanpour and Schwab [16]. Both leaf digests and soil extracts were analyzed using absorption spectroscopy. The data was tabulated using minimum, maximum, mean and standard deviation obtained through descriptive statistics.

\section{Results and discussion Soil characteristics}

Citrus orchard soils of district Swabi were light textured with sandy loam as a dominant texture $(60 \%)$ in each village, with remaining being silt loam, loamy sand and loam. $\mathrm{pH}$ was between 7.59-7.80 with mean value of 7.69 , all falling under medium alkaline (7.5-8.3) category. All the soils under micronutrient survey were non-saline in nature with electrical conductivity (EC) values ranging between 
0.09-0.20 dS $\mathrm{m}^{-1}$ (mean $0.13 \mathrm{dS} \quad \mathrm{m}^{-1}$ ). Organic matter content of the soils was between $1.19-6.72 \%$, with mean value of $2.51 \%$. Each $100 \%$ soils of Topi and
Gadoon, and each $80 \%$ of Jhanda and Mani were adequate $(>1.29 \%)$ in organic matter content, while remaining $20 \%$ were medium (0.86-1.29\%) (Table 1).

Table 1. Summary characteristics of citrus orchard soils in District Swabi, Khyber Pakhtunkhwa

\begin{tabular}{|c|c|c|}
\hline Soil property & Range & Mean \pm SD \\
\hline $\mathrm{pH}^{*}$ & $7.59-7.80$ & $7.69 \pm 0.056$ \\
\hline${\mathrm{EC}\left(\mathrm{dSm}^{-1}\right)^{*}}^{*}$ & $0.09-0.20$ & $0.13 \pm 0.027$ \\
\hline Organic matter $(\%)$ & $1.19-6.72$ & $2.51 \pm 1.29$ \\
\hline Sand $(\%)$ & $24.0-85.0$ & $62.33 \pm 17.34$ \\
\hline Silt $(\%)$ & $10.40-70.00$ & $32.00 \pm 16.41$ \\
\hline Clay $(\%)$ & $2.60-11.50$ & $5.76 \pm 2.46$ \\
\hline
\end{tabular}

*1:2 soil water extract

\section{Soil micronutrients}

Soil analysis (Table 2) indicated that available $\mathrm{B}$ ranged from 0.67 to $13.77 \mathrm{mg}$ $\mathrm{kg}^{-1}, \mathrm{Cu}$ from $0.48-3.72 \mathrm{mg} \mathrm{kg}^{-1}, \mathrm{Fe}$ from $1.43-14.46 \mathrm{mg} \mathrm{kg}^{-1}$, Mn from 0.30-10.22 and $\mathrm{Zn}$ from $0.52-5.39 \mathrm{mg} \mathrm{kg}$. The respective mean values were in $\mathrm{mg} \mathrm{kg}^{-1}$ were: $4.52(\mathrm{~B}), 1.95(\mathrm{Cu}), 6.47(\mathrm{Fe}), 4.13$ $(\mathrm{Mn})$ and $2.28(\mathrm{Zn})$. Further, majority of the soils of citrus orchards were adequate each in $\mathrm{B}$ and $\mathrm{Cu}(95 \%), \mathrm{Fe}(65 \%), \mathrm{Mn}$ $(60 \%)$ and $\mathrm{Zn}(55 \%)$ [16, 17]. However, the remaining soils both, either marginal or low, were below the adequate limit of 1.0 $\mathrm{mg} \mathrm{kg}^{-1} \mathrm{~B}(5 \%), 0.5 \mathrm{mg} \mathrm{kg}^{-1} \mathrm{Cu}(5 \%), 4.0$ $\mathrm{mg} \mathrm{kg}{ }^{-1} \mathrm{Fe}(25 \%), 1.8 \mathrm{mg} \mathrm{kg}^{-1} \mathrm{Mn}(40 \%)$ and $1.5 \mathrm{mg} \mathrm{kg}^{-1} \mathrm{Zn}(45 \%)$. These results clearly show the major deficiencies of $\mathrm{Zn}$, $\mathrm{Mn}, \mathrm{Fe}$ and to some extent for $\mathrm{B}$ and $\mathrm{Cu}$. The results are somewhat similar to those given by Zia et al. [18] for orchard soils in Pakistan. Their data depicted that $68 \%$ soils in $\mathrm{Zn}, 28 \%$ in $\mathrm{Fe}, 8 \%$ in $\mathrm{Mn}$ and $2 \%$ in $\mathrm{Cu}$ were deficient under citrus plantation. Results published by Shah et al. [5] relating to citrus orchards in Swat valley of KPK, further supported this research. They reported that $\mathrm{B}$ and $\mathrm{Cu}$ were in adequate ranges, however, $\mathrm{Fe}(12-$ $18 \%), \mathrm{Mn}(4-14 \%)$ and $\mathrm{Zn}(10-44 \%)$ were found to be deficient.

\section{Leaf tissue micronutrients}

In contrast to soil, majority of the leaf tissue analysis of citrus orchards depicted deficiency of micronutrients. Boron ranged from 1.10-51.75 (mean 22.64), $\mathrm{Cu} 3.90-$ 11.98 (mean 6.93), Fe 118-398 (188.4), Mn 6.97-26.95 (mean 13.0), and Zn 10.2817.65 (mean 12.94) in $\mathrm{mg} \mathrm{kg}^{-1}$ soil. Categorization of leaf tissue values showed that majority of the samples fell either under 'marginal' or 'low' category, being below the required level of adequacy. This way, $100 \%$ samples of each B (100 mg kg-1), Cu (100 mg kg-1), Mn (200 mg kg-1), Zn (200 mg kg-1) and $70 \%$ samples of $\mathrm{Fe}\left(150 \mathrm{mg} \mathrm{kg}^{-1}\right)$ were below the respective adequacy levels. The details are covered under (Table 2). Analyzing the data with regard to leaf tissue analysis of the region illustrates a continual and measured history of micronutrient status. Early survey reports [19] showed no micronutrient deficiencies. Few years after, some of the orchards belonging to same area pertaining to leaf tissue analysis depicted that $50 \%$ samples were deficient in $\mathrm{Zn}$ and only $5 \%$ in B [20]. Similar results were reported by [21] for $\mathrm{Zn}$, during the same period. However, in addition to $\mathrm{Zn}$, they also reported deficiency of $\mathrm{B}, \mathrm{Cu}, \mathrm{Fe}, \mathrm{Mn}$ (50-60\% samples). Not many studies were conducted during that period. Later on, $\mathrm{Zn}$ in leaf tissue had been the most common deficient nutrient [22-24]. Similar results have been reported for citrus orchards in Malakand division [5]. The percent leaf samples being low in micronutrients were $\mathrm{B}(24 \%), \mathrm{Cu}$ (16\%), Mn (96\%) and $\mathrm{Zn}$ 
(100\%). These reports show a gradual decrease in micronutrient stocks. In practice, the growers of district Swabi are not in practice of micronutrient application. However, the present status suggests that without micronutrient application in sweet orange orchards, the quality and production may further decline.

\section{Association between soil}

\section{characteristics/available and leaf tissue micronutrients}

Soil properties i.e. sand, silt, clay, $\mathrm{pH}, \mathrm{EC}$ and organic matter contents were individually correlated with available nutrients (i.e. $\mathrm{B}, \mathrm{Cu}, \mathrm{Fe}, \mathrm{Mn}$ and $\mathrm{Zn}$ ) of soil. The association (i.e. coefficient of correlation) between the two is given in (Table 3). The association was generally non-significant except in case of organic matter. The association was linear and positive for $\mathrm{B}(0.53), \mathrm{Fe}(0.67)$ and $\mathrm{Zn}$ (0.80) showing a nutrient enrichment from this pool.

Research relevant to this topic have reported positive, linear and significant association of organic matter content with available micronutrients [25-28]. This study reports negative association of $\mathrm{pH}$ with $\mathrm{B}, \mathrm{Fe}, \mathrm{Mn}$ and $\mathrm{Zn}$ except with $\mathrm{Cu}$ (0.60). These results are supported by Ibrahim et al. [27]. They also reported a positive association between $\mathrm{pH}$ and $\mathrm{Cu}$. Association between $\mathrm{EC}$ and $\mathrm{Cu}, \mathrm{Fe}, \mathrm{Mn}$ and $\mathrm{Zn}$ was generally negative, except in case of B (0.17), which was positive. This is in agreement with the results reported by [26]. This study also reports positive and significant relationship between silt and $\mathrm{Cu}$ contents which again was supported by Ibrahim et al. [27].

Table 2. Micronutrient contents in soil and relevant leaf tissue samples of citrus orchards in District Swabi, Khyber Pakhtunkhwa

\begin{tabular}{|c|c|c|c|c|c|}
\hline \multirow{2}{*}{ Nutrient } & Range & Mean \pm S.D & \multicolumn{3}{|c|}{ Categorization (\% samples) } \\
\hline & \multicolumn{2}{|c|}{$\left(\mathrm{mg} \mathrm{kg}^{-1}\right)$} & Low & Marginal & Adequate \\
\hline \multicolumn{6}{|c|}{ Plant available } \\
\hline $\mathrm{HCl}$ extractable $\mathrm{B}$ & $0.67-13.77$ & $4.52 \pm 2.75$ & $\frac{<0.45}{0}$ & $\frac{0.45-1.0}{5}$ & $\frac{>1.0}{95}$ \\
\hline AB-DTPA extractable $\mathrm{Cu}$ & $0.48-3.72$ & $1.95 \pm 0.95$ & $\frac{<0.2}{5}$ & - & $\frac{>0.5}{95}$ \\
\hline AB-DTPA extractable Fe & $1.43-14.46$ & $6.47 \pm 3.37$ & $\frac{<2.0}{20}$ & $\frac{2.1-4.0}{15}$ & $\frac{>4.0}{65}$ \\
\hline AB-DTPA extractable Mn & $0.30-10.22$ & $4.13 \pm 3.25$ & $\frac{<1.8}{40}$ & - & $\frac{>1.8}{60}$ \\
\hline AB-DTPA extractable Zn & $0.52-5.39$ & $2.28 \pm 1.50$ & $\frac{<0.9}{10}$ & $\frac{0.9-1.5}{35}$ & $\frac{>1.5}{55}$ \\
\hline 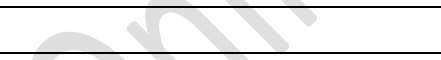 & & Leaf tissue & & & \\
\hline $\mathrm{B}$ & $1.10-51.75$ & $22.64 \pm 13.94$ & $\frac{<25}{45}$ & $\frac{25-100}{55}$ & $\frac{>100}{-}$ \\
\hline $\mathrm{Cu}$ & $3.90-11.98$ & $6.93 \pm 1.80$ & $\frac{<6}{40}$ & $\frac{6-100}{60}$ & $\frac{>100}{-}$ \\
\hline $\mathrm{Fe}$ & $118-398$ & $188.4 \pm 65.97$ & $\frac{\leq 60}{-}$ & $\frac{60-150}{70}$ & $\frac{>150}{30}$ \\
\hline $\mathrm{Mn}$ & $6.97-26.95$ & $13.00 \pm 4.25$ & $\frac{<25}{95}$ & $\frac{25-100}{5}$ & $\frac{>200}{-}$ \\
\hline $\mathrm{Zn}$ & $\begin{array}{l}10-28- \\
17.65\end{array}$ & $12.94 \pm 4.25$ & $\frac{<25}{100}$ & $\frac{25-200}{-}$ & $\frac{>200}{-}$ \\
\hline
\end{tabular}

Note: The values underlined are the critical limits of the given nutrient in $\mathrm{mg} \mathrm{kg}^{-1}$ 
Table 3. Coefficient of correlation ( $r$ value) between soil characteristics and soil micronutrient contents $\left(\mathrm{mg} \mathrm{kg}^{-1}\right)$

\begin{tabular}{|c|c|c|c|c|c|}
\hline Soil properties & $\mathbf{B}$ & $\mathbf{C u}$ & $\mathbf{F e}$ & $\mathbf{M n}$ & $\mathbf{Z n}$ \\
\hline $\mathrm{pH}$ & $-0.31 \mathrm{NS}$ & $0.60^{* *}$ & $-0.47^{*}$ & $0.14 \mathrm{NS}$ & $-0.51^{*}$ \\
\hline $\mathrm{EC}\left(\mathrm{dS} \mathrm{m}^{-1}\right)$ & $0.17 \mathrm{NS}$ & $-0.08 \mathrm{NS}$ & $-0.04 \mathrm{NS}$ & $-0.41^{*}$ & $-0.18 \mathrm{NS}$ \\
\hline Organic matter $(\%)_{\text {Sand }(\%)}^{0.53^{*}}$ & $0.32 \mathrm{NS}$ & $0.67^{* *}$ & $0.35 \mathrm{NS}$ & $0.80^{*}$ \\
\hline Silt (\%) & $0.28 \mathrm{NS}$ & $-0.47^{*}$ & $0.10 \mathrm{NS}$ & $0.05 \mathrm{NS}$ & $-0.19 \mathrm{NS}$ \\
\hline Clay (\%) & $-0.27 \mathrm{NS}$ & $0.44^{*}$ & $-0.09 \mathrm{NS}$ & $-0.05 \mathrm{NS}$ & $0.16 \mathrm{NS}$ \\
\hline$-0.13 \mathrm{NS}$ & $0.35 \mathrm{NS}$ & $-0.11 \mathrm{NS}$ & $-0.10 \mathrm{NS}$ & $0.24 \mathrm{NS}$ \\
\hline
\end{tabular}

"Significant at $5 \%$ level

Regression between soil and leaf tissue nutrients: The available $\mathrm{B}, \mathrm{Cu}, \mathrm{Fe}, \mathrm{Mn}$ and $\mathrm{Zn}$ when individually regressed with their respective leaf tissue nutrient contents. The regression coefficient $\left(\mathrm{R}^{2}\right)$ explained a non-significant relationship with only $26 \%(\mathrm{~B}), 3 \%(\mathrm{Cu}), 21 \%(\mathrm{Fe})$, and $18 \%(\mathrm{Mn})$ contribution due to soil available micronutrients, however, there was no relationship between soil and leaf tissue of $\mathrm{Zn}$. This is further described by the regression equations. in case of organic matter. The association was linear and positive for $\mathrm{B}(0.53), \mathrm{Fe}(0.67)$ and $\mathrm{Zn}$ (0.80) showing a nutrient enrichment from this pool.

Boron: $\mathrm{Y}=4.15 \mathrm{x}+6.55, \mathrm{R}^{2}=0.26$; Copper: $\mathrm{Y}=0.36 \mathrm{x}+6.42, \mathrm{R}^{2}=0.03$

Iron: $\mathrm{Y}=5.92 \mathrm{x}+138.97, \mathrm{R}^{2}=0.21$; Manganese: $Y=0.35 x+9.89, R^{2}=0.18$

Zinc: $\mathrm{Y}=-0.08 \mathrm{x}+13.10, \mathrm{R}^{2}=0.0006$

Poor and non-significant associations between available nutrients in soil and total nutrient contents in leaf tissue are already expected, exclusively for the fruit perennial crops $[10,29]$. Soil nutrient contents are actually the one time attempt, while the leaf tissue contents have been accumulated over time and based on the past nutrient application. The matter of the fact that the soil nutrient contents do not associate with leaf tissue contents as the soil samples do not represent whole root area [30]. Soil test values have a lot to do with the way samples have been collected i.e. time of sampling, area considered, composite sampling, fertilizer history, etc.

\section{Fertilizer management}

All four villages (Jhanda, Manai, Topi and Gadoon) of district Swabi under sweet orange cultivation were not in practice of micronutrient fertilizer application, even the major nutrients were applied in meager amounts ( $\mathrm{N}$ and $\mathrm{P}$ ) with no $\mathrm{K}$ (Table 4).

Table 4. Fertilization practices of citrus growers in district Swabi, Khyber Pakhtunkhwa

\begin{tabular}{|c|c|c|c|}
\hline Site No. & $\mathrm{N}+\mathrm{P}_{2} \mathrm{O}_{5}\left(\mathrm{~kg} \mathrm{ha}^{-1}\right)$ & Site No. & $\mathrm{N}+\mathrm{P}_{2} \mathrm{O}_{5}\left(\mathrm{~kg} \mathrm{ha}^{-1}\right)$ \\
\hline 1 & $58+35$ & 11 & $46+23$ \\
\hline 2 & $69+35$ & 12 & $58+35$ \\
\hline 3 & $96+58$ & 13 & $69+35$ \\
\hline 4 & $58+35$ & 14 & $58+35$ \\
\hline 5 & $81+46$ & 15 & $46+23$ \\
\hline 6 & $69+46$ & 16 & $58+35$ \\
\hline 7 & $46+23$ & 17 & $69+35$ \\
\hline 8 & $81+46$ & 18 & $92+46$ \\
\hline 9 & $92+46$ & 19 & $81+46$ \\
\hline 10 & $69+35$ & 20 & $69+35$ \\
\hline
\end{tabular}

Each $25 \%$ citrus growers applied N-P at $58-35$ and $69-35 \mathrm{~kg} \mathrm{ha}^{-1}$, each $3 \%$ at $46-23$ and $81-46 \mathrm{~kg} \mathrm{ha}^{-1}, 2 \%$ at $92-46 \mathrm{~kg} \mathrm{ha}^{-1}$ and each $1 \%$ at $69-46$ and $96-58 \mathrm{~kg} \mathrm{ha}^{-1}$, 
respectively. Tariq et al. [7] reported maximum yield of sweet orange, blood red variety using $0.4-0.2-1.56 \mathrm{~kg}$ of $\mathrm{Zn}-\mathrm{Mn}-\mathrm{N}$ $\mathrm{ha}^{-1}$ with $0.4 \mathrm{~kg}$ of surfactance. Each micronutrient played a different role by increasing \% juice (B), reducing sugar $(\mathrm{Mn})$ and vitamin $\mathrm{C}(\mathrm{B}+\mathrm{Zn})$. Fertilizer management of fruit trees varies in the sense that nutrients are required throughout the growth period from one harvesting to other, considering the type and quantity of nutrient and the growth stage in particular. There are three important growth stages; cell division, a slow growth period lasing for about two months, rise in fruit size and water buildup, a rapid growth for about four to six months, and the last one is fruit ripening [31]. Actually, each growth stage is dependent on the previous stage [32], therefore, optimal nutrient status at these growth stages will determine the yield and quality of fruit. Other than major nutrient application, citrus crop require micronutrients such as $\mathrm{B}, \mathrm{Cu}, \mathrm{Fe}, \mathrm{Mn}$ and $\mathrm{Zn}$. Foliar application of these nutrients have been promoted widely due to their rapid response, effectiveness, ease in removing toxicity, etc. however, it is only beneficial when the deficiency symptoms appear and it not transferred into soil for further utilization [7, 33, 34]. General guidelines for the application of micronutrients for fruit crops are covered elsewhere [18].

\section{Conclusion}

The soils of the study area were light textured. In the absence of fertilizer application, high organic matter contents, and to some extent positive relationship of organic matter with micronutrients, it is obvious that the nutrient enrichment in soils is due to organic matter fraction and may also be based on the parent material containing different nutrients, which needs to be explored in future studies. Leaf tissue analysis was in contrast to soil analysis and illustrated that majority of the samples were below the relevant critical for $\mathrm{B}, \mathrm{Cu}$, $\mathrm{Fe}, \mathrm{Mn}$ and $\mathrm{Zn}$. Based on this study, it is suggested that other than major nutrients, application of $\mathrm{B}, \mathrm{Cu}, \mathrm{Fe}, \mathrm{Mn}$ and $\mathrm{Zn}$ should be included in the regular fertilizer schedule. Specific fertilizer applications can be based on the soil and leaf tissue tests carried out for three consecutive years.

\section{Authors' contributions}

Conceived and designed the experiments: M Memon \& NN Memon, Performed the experiments: MS Jadoon, Analyzed the data: MN Kandhro, Contributed materials/ analysis/ tools: Hidayatullah \& MS Jadoon, Wrote the paper: M Memon \& TA Sial.

\section{References}

1. Anonymous (2012). Key industry statistics for citrus growers. Citrus growers association of Southern Africa, pp 48.

2. GoP (2012). Agricultural statistics of Pakistan. Ministry of National Food Security and Research, Government of Pakistan, pp 272.

3. GoP (2006). Agriculture Statistics of Pakistan. Ministry of Food, Agriculture and Livestock (Economic Wing), Government of Pakistan, Islamabad, Pakistan.

4. MINFAL (2006). Agricultural statistics of Pakistan. Govt. of Pakistan. Ministry of food Agriculture Livestock, Food Agriculture and livestock Division (Economic Wing) Islamabad, Pakistan.

5. Shah Z, Shah MZ, Tariq M, Bakht J \& Rahman H (2012). Survey of citrus orchards for micronutrients deficiency in Swat valley of Khyber Pakhtunkhwa Pakistan. Pak J Bot 44(2): 705-710.

6. Ahmed A \& Saleem MT (2006). Citrus and its nutrition. Farming Outlook 5(1): 11-19.

7. Tariq M, Sharif M, Shah Z \& Khan R (2007). Effect of foliar application of micronutrients on the yield and quality of sweet orange (Citrus sinensis L.). Pak J Biol Sci 10(11): 1823-1828. 
8. Takano J, Miwa $\mathrm{K}$ \& Fujiwara $\mathrm{T}$ (2008). Boron transport mechanisms: collaboration of channels and transporters. Trends in Plant Sci 13: 451-457.

9. Khurshid F, Khattak RA \& Sarwar S (2008). Effect of foliar applied (Zn, $\mathrm{Fe}, \mathrm{Cu} \& \mathrm{Mn})$ in citrus production. Sci Tech Develop 27 (1\&2): 34-42.

10. Shah Z \& Shahzad K (2008). Micronutrients status of apple orchards in Swat valley of North West frontier province of Pakistan. Soil Environ 27(1): 123-130.

11. Jones JB Wolf Jr, B \& Mills HA (1991). Plant analysis handbook. Micro macro publishing, Inc., USA.

12. Sonneveled C \& Dijk PAV (1982). The effectiveness of some washing procedures on the removal of contaminates from plant tissues of glasshouse crops. Commun Soil Sci Plant Anal 13: 487-496.

13. Ryan J, Estefan G \& Rashid A (2001). Soils and Plant Analysis Laboratory Manual. Second Edition, jointly published by the International Center for Agricultural Research in the Dry Areas (ICARDA) and the National Agricultural Research Center (NARC), available from ICRADA, Aleppo, Syria, pp 172.

14. Jones TB \& W Case (1990). Sampling, handling and analyzing plant tissue samples. In Soil tasting and plant analysis. $3^{\text {rd }}$ addition. Westerman, R.L. (ed). Soil Sci Soc Am Inc. Madison, Wisconsin, USA.

15. Bingham FT (1982). Boron. In A. L. Page (ed.), Methods of soil analysis, Part 2: Chemical and mineralogical properties. Am Soc Agron Madison, WI, USA. pp 431-448.

16. Soltanpour PN \& AP Schwab (1977). A new soil test for simultaneous extraction of macro- and micronutrients in alkaline soils. Commun Soil Sci Plant Anal 8: 195-207.

17. Johnson GV \& PE Fixen (1990). Testing soils for sulfur, boron, molybdenum, and chlorine. p. 265273 In RL Westerman (ed.), Soil testing and plant analysis, 3rd ed., Soil Sci Soc Am, Madison. WI, USA.

18. Zia MJ, Ahmad R, Khaliq I, Ahmad A \& Irshad M (2006). Micronutrient status and management in orchard soil: applied aspects. Soil Environ 25(1): 6-16.

19. Rehman H (1990). Annual report. Directorate of soil and plant nutrition, ARI Tarnab, Peshawar, NWFP. Pakistan. Directorate of soil and plant nutrition, ARI Tarnab, Peshawar, NWFP.

20. Ha, IU, Ghani A \& Rehman HU (1995). Nutritional status of citrus orchards in NWFP and the effect of fertilizer application on fruit production. Directorate of soils and plant Nutrition, A.R.I, Tarnab, Peshawar, NWFP Pakistan. Technical Bulletin 1/95.

21. Khattak JK (1995). Micronutrients in Pakistan agriculture. Pakistan Agricultural Research Council and department of soil science, NWFP agricultural university, Peshawar.

22. Khattak R \& Hussain Z (2007). Evaluation of soil fertility status and nutrition of orchards. Soil Environ 26(1): 22-32.

23. Rashid A, Yaseen M, Ali MA, Ahmed Z \& Ullah R (2006). Residual and cumulative effect of boron use in ricewheat system in calcareous soils of Pakistan. $18^{\text {th }}$ world congress of soil science, July 9-15, Philadelphia, Pennsylvania, USA.

24. Dursu, A, Turan M, Ekinci M, Gunes A, Ataoghu N, Esringu A \& Yildirim E (2010). Effect of boron fertilizer on tomato, pepper and cucumber yields and chemical composition. Commun Soil Sci Plant Anal 41: 1576-1593.

25. Nazif W, Perveen S \& Saleem I (2006). Status of micronutrients in soils of district Bhimber (Azad Jammu and Kashmir). J Agric Biol Sci 1(2): 35-40. 
26. Sarwar S, Perveen S, Shoaib M, Ahmad F \& Khan J (2007). To study the correlation of micronutrients with physico-chemical properties of soils of district Palandri (Azad Kashmir). Sarhad J Agric 23(3): 655-665.

27. Ibrahim AK, Usman A, Abubakar B \& Aminu UH (2011). Extractable micronutrients status in relation to other soil properties in Billiri Local Government Area. J Soil Sci Environ Manage 3(10):282-285.

28. Chandrakar K, Srivastava LK, \& Devdas D (2013). Estimation of available micronutrients on the basis of correlation between physicochemical properties of $\mathrm{pH}, \mathrm{EC}, \mathrm{OC}$ and available $\mathrm{Fe}, \mathrm{Mn}, \mathrm{Cu}$ and $\mathrm{Zn}$ in Inceptisol of Akaltara block of Janjgir district of Chhattisgarh. Asian J Soil Sci 8(2): 416-418.

29. Zia MS, Aslam M, Cheema NM, Shah A \& Laghari H (2004). Diagnosis of plant nutrient disorder in fruit plants. p. 16-27. In Proceedings of Symposium on Plant-Nutrition Management for Horticultural Crops under Water-Stress Conditions (M. Ibrahim, ed.), organized by SSSP, ARI, Sariab, Quetta, and PSF on October 5-6, 2004 at ARI Sariab, Quetta, Balochistan.

30. Aziz T, Gill MA, Rahmatullah \& Sabir M (2004). Mineral nutrition of fruit trees. In: Proceedings of symposium on plant-nutrition management for horticultural crops under water-stress conditions. (Ed.): M. Ibrahim, organized by Soil Science Society of Pakistan, Agriculture Research Institute (ARI), Sariab, Quetta, and PSF on October 5-6, 2004 at ARI Sariab, Quetta, Balochistan. pp 28-33.

31. Iglesias DJ, Cercós M, ColmeneroFlores JM, Naranjo MA, Ríos G, Carrera E, Ruiz-Rivero O, Lliso I, Morillon R, Tadeo FR \& Talon $M$ (2007). Physiology of citrus fruiting. Braz J Plant Physiol 19(4): 333-362.

32. Mehouachi J, Serna D, Zaragoza S, Agusti M, Talon M, Primo-Millo E (1995) Defoliation increases fruit abscission and reduces carbohydrate levels in developing fruits and woody tissues of Citrus Unshiu. Plant Sci. 107:189-197.

33. Navrot J \& Banin A (1982). Trunk implanted zinc-bentonite as a source of zinc for apple trees. Plant Soil 69: 85-95.

34. Perveen S and Rehman H (2000). Effect of foliar application of zinc, manganese and boron in combination with urea on the yield of sweet orange. Pak J Agric Res 16: 135-141. 